\title{
Çiğ Süt Örneklerinde Ağır Metal ve Metal Kontaminasyonlarının Belirlenmesi ve Sağlık Üzerine Etkisi
}

\author{
Murat KILIÇ⿻,1,* Ogün BOZKAYA \\ ${ }^{1}$ Ankara Üniversitesi, Sağllk Hizmetleri Meslek Yüksekokulu, Eczane Hizmetleri Programı, Ankara, Türkiye \\ ${ }^{2}$ Kırıkkale Üniversitesi, Bilimsel ve Teknolojik Araștırmalar Uygulama ve Araştırma Merkezi (KÜBTUAM), \\ Kırlkkale, Türkiye
}

*Sorumlu Yazar: mrtkilic@ankara.edu.tr

\begin{abstract}
Özet
Artan teknolojik gelişmeler, aynı zamanda, çevre kirliliğini de beraberinde getirmektedir. Toprak, su ve havada endüstrileşmenin bir sonucu olarak artan ağır metaller ve metalik birleşikler, besin zinciri yoluyla insan ve hayvanlara geçmekte ve sağlik üzerinde olumsuz etki oluşturmaktadır. Bu çalıșmada, Denizli ili Acıpayam ilçesi Yumrutaş (Yumrutaş 1. ve 2. Bölge), Bademli ve Kargın Beldelerinde bulunan çiğ süt toplama merkezlerinden alınan 4 farklı çiğ süt numunesinde Kurşun $(\mathrm{Pb})$, Kadmiyum $(\mathrm{Cd})$ ağır metalleri ile bakır $(\mathrm{Cu})$, kobalt (Co) ve krom $(\mathrm{Cr})$ metallerinin miktarlarının belirlenmesini amaçladık. Toplanan süt örneklerinde belirtilen ağır metal ve metallerin miktarları atomik absorbsiyon spektrofotometresi (AAS) cihazında spektrofotometrik olarak belirlenmiştir. Buna göre $\mathrm{Pb}$, en yüksek oranda Kargın Beldesi'nde (0,574 ppm); Cd, en yüksek Yumrutaş Beldesi 2 . Bölgede (0,567 ppm); $\mathrm{Cu}$, en yüksek Kargın Beldesi'nde (0,067 ppm); $\mathrm{Cr}$, en yüksek Yumrutaş Beldesi 1. Bölgede (0,245 ppm) ve Co, en yüksek Kargın Beldesi'nde $(0,45 \mathrm{ppm})$ toplanan süt örneklerinde görülmüştür. Tüketime sunulmak için toplanan çiğ süt örneklerinde metal ve ağır metal kontaminasyon varlığının sağllk üzerinde tehdit oluşturduğunu ve bu kontaminantların bulaşma yollarının belirlenip önlem alınması gerektiğini düşünüyoruz.
\end{abstract}

Anahtar Kelimeler: Ağır Metal Kontaminasyonu, Çiğ Süt, Atomik Absorbsiyon Spektrofotometresi

\begin{abstract}
Increasing technological developments, at the same time, bring environmental pollution. Increasing heavy metals and metallic compounds in soil, water and air as a result of industrialization pass through the food chain to humans and animals and have a negative effect on health. In this study, we aimed to determine the amounts of lead $(\mathrm{Pb})$, cadmium $(\mathrm{Cd})$ heavy metals and copper $(\mathrm{Cu})$, cobalt $(\mathrm{Co})$ and chromium $(\mathrm{Cr})$ metals in 4 different raw milk samples taken from raw milk collection centers in Yumrutaş (Yumrutaş 1st and 2nd Region), Bademli and Kargin Districts of Acıpayam in Denizli. The quantities of heavy metals and metals in the collected milk samples were determined spectrophotometrically in the atomic absorption spectrophotometer (AAS). Accordingly, $\mathrm{Pb}$ was highest in the Kargin District (0.574 ppm); Cd was highest in Yumurutaş District 2nd Region (0.567 ppm); Cu was highest in Kargın District (0.067 ppm); Cr was highest in Yumurutaş District 1st Region $(0.245 \mathrm{ppm})$ and Co was highest in Kargin $(0.45 \mathrm{ppm})$ in collected raw milk samples. We think that the presence of metal and heavy metal contamination in raw milk samples collected for presentation on the market poses a health threat and it is necessary to determine the ways of contamination and to take precautions of these contaminants.
\end{abstract}

Keywords: Heavy Metal Contamination, Raw Milk, Atomic Absorption Spectrophotometer 


\section{Giriş}

Teknolojinin hızla gelişmesi, gelişen teknolojiyle endüstrileşmenin artması ve bunun sonucunda da üretimin artması, insan hayatını kolaylaştırırken, bunun paralelinde tüketimin artması da doğal ve ekolojik dengenin bozulmasına neden olmaktadır. Üretimin arttırılması amacıyla doğal kaynaklardan elde edilen ham maddelerin gerekli gereksiz kullanımı beraberinde çevre kirliliğini getirmektedir (Licata ve ark., 2004). Ekosistem, kendi homeostazisini sağlamada her ne kadar yüksek başarı gösterse de, biz insanlar bu homeostazik dengeyi bozma konusunda ondan daha fazla çaba sarf etmekteyiz. Çevre kirlenmesi daha çok biyolojik etmenlerden kaynakladığı düşünülse de, aslında kimyasal kontaminantların etkisinin de unutulmaması gerekir. Bu kimyasal kontaminantlardan birisini de, genel olarak çevre kirliliğine neden olan ve insan sağlığı üzerinde olumsuz etkileri olan metaller ile metalloidler olarak adlandırılan, krom $(\mathrm{Cr})$, kurşun $(\mathrm{Pb})$, kadmiyum $(\mathrm{Cd}), \operatorname{demir}(\mathrm{Fe})$, kobalt $(\mathrm{Co})$, bakır $(\mathrm{Cu})$, kalay $(\mathrm{Sn})$, alüminyum $(\mathrm{Al})$, nikel $(\mathrm{Ni})$, civa $(\mathrm{Hg})$ ve çinko $(\mathrm{Zn})$ gibi 60'tan fazla metal ile metal olmayan grupta yer alan arsenik (As) ve selenyum (Se) gibi elementlerin oluşturduğu ağır metaller oluşturmaktadır (Duffus, 2002; Jarup, 2003; Türközü ve ark., 2014).

Gıdanın yapısında doğal olarak bulunmayan ağır metal iyonları, toprak, su ve havadan, teknolojik olarak gıdalarda üretim esnasında kullanılan metalik alet ve ekipmanlardan, depolama ve dağıtım sırasında kullanılan ambalaj materyallerinden gıdalara bulaşmaktadır (Türközü ve ark., 2014). Gıdalara belirtilen bu bulaşma kaynaklarından bulaşan ağır metal iyonları hem insan, hem de hayvan sağlığına ciddi zararlar verirken; aynı zamanda da gıda sanayiinde de, ticari açıdan önemli derecede zararlara yol açabilmektedir (İnci ve ark., 2017).

Süt kendi başına ve/veya kendisinden yapılan çeşitli süt ürünleri olarak, insan beslenmesinde kullanılan temel bir gıdadır. Günümüzde, besin içeriğince zengin yüksek biyolojik değerlere sahip olması, sağlık açısından çok az risk taşıdığının düşünülmesi ve özellikle kolay ulaşılabilir ve ucuz olmasından dolayı geçmişe oranla, süt ve ürünleri tüketiciler tarafından daha fazla tercih edilir hale gelmiştir. Ancak, hayvanlarda meme bezlerinin bir salgısı olarak salgılanan süt, günlük üretilen süt ürünlerinde teknolojik risk oluşturan ve her şeyden daha önemlisi insan sağlığı açısından tehlikeli olan tarım ilaçları, deterjanlar, ilaç artıkları, metal iyonları ve çevresel kirleticiler gibi birçok ksenobiyotiği barındırabilir (Licata ve ark., 2004). Bu nedenle, sütteki ağır metal iyonlarının konsantrasyonlarının belirlenmesi, süt ve süt ürünlerinin hijyenik durumunun bir doğrudan göstergesi olabileceği gibi, sütünden yararlanılan hayvanların yaşadığı ve beslendiği çevrenin kirlilik oranının da dolaylı göstergesi olabilir.

Yapılan birçok uluslararası çalışma, başta $\mathrm{Pb}, \mathrm{Cd}$ ve $\mathrm{Zn}$ olmak üzere süt ve ürünlerinde bir çok ağır metal kontaminasyonunun varlığını rapor etmiştir (Baldini ve ark., 1990; Jorhem ve ark., 1991; Pittia ve ark, 1992; Kincaid and Cronrath, 1992; Salvato ve ark., 1992; Coni ve ark., 1994, 1995, 1996; Campillo ve ark., 1998; Krachler ve ark., 1998; Imparato ve ark., 1999; Bratakos ve ark., 2001; Licata ve ark., 2004). Ancak bu çalışmalar, araştırmacıların kendi ülkelerinde ve ülkelerinin farklı bölgelerinde yapılmış olup, farklı sonuçlar göstermektedir. Ülkemizde yapılan çalışmalara bakıldığında ise, Simsek ve ark. (2000), Bursa ve çevresinde; Temurci ve ark. (2006), Ankara ve çevresinde; Ayar ve ark. (2007), Konya ve çevresinde; Bıgucu ve ark. (2016), Çanakkale ve çevresinde; İnci ve ark. (2017), Aydın ve çevresinde yaptıkları çalışmalarda süt ve ürünlerinde $\mathrm{Al}, \mathrm{As}, \mathrm{Cd}, \mathrm{Cr}, \mathrm{Co}, \mathrm{Cu}, \mathrm{Fe}, \mathrm{Ni}, \mathrm{Mn}, \mathrm{Pb}$ ve $\mathrm{Se}$ gibi metallerin kontaminasyonlarını bildirmişlerdir.

Denizli; Gıda, Tarım ve Hayvancılık Bakanlığı ve Türkiye İstatistik Kurumu (TÜİK)'nun 2015 yılı verilerine göre sadece 228,564 büyük baş hayvan ve günlük yaklaşık 1700 ton sütün toplandığı, sahip olduğu irili ufaklı 29 işletmede işlendiği ve tüketim için pazara sunulduğu bir ilimiz olmakla birlikte (http://www.tarim.gov.tr/SGB/TARYAT/Belgeler/il_yatirim_rehberleri/denizli.pdf); Acıpayam ilçesi bu istatistiklere en fazla katkı sağlayan ilçesi olmuştur. Ancak süt ve ürünleri bakımından ülkemizin önde gelen bu bölgesinde toplanan süt örneklerinde, kimyasal kontaminantların miktarı ve önemi hakkında pek fazla sayıda çalışma görülmemektedir. Dolayısıyla bu çalışmada, Denizli ili Acıpayam 
İlçesi, Yumrutaş, Bademli ve Kargın beldelerinde bulunan süt toplama merkezlerinden alınan çiğ süt örneklerinde, Kurşun $(\mathrm{Pb})$, Kobalt (Co), Kadmiyum $(\mathrm{Cd})$, Krom $(\mathrm{Cr})$ ve Bakır $(\mathrm{Cu})$ metallerinin kontaminasyon belirlenmesi amaçlanmıştır.

\section{Materyal ve Metot}

Bu çalışmada, 2012 yılında, Denizli ili Acıpayam ilçesi Yumrutaş, Bademli ve Kargın Beldeleri süt toplama merkezlerinden; Yumrutaş 1. ve 2. Bölge, Bademli ve Kargın olmak üzere alınan 4 adet çiğ süt örneği çalışılmıştır. Çiğ süt örnekleri plastik tüplere alındıktan sonra $-20^{\circ} \mathrm{C}$ 'de çalışılacağı süreye kadar muhafaza edildi. Çalışmanın laboratuar analizleri Kırıkkale Üniversitesi Bilimsel ve Teknolojik Araştırmalar Uygulama ve Araştırma Merkezi (KÜBTUAM)'inde gerçekleştirildi. Öncelikle, $50 \mathrm{~g}$ katı trikloroasetik asit (TCA), $250 \mathrm{~mL}$ saf suda çözdürüldü ve böylece $250 \mathrm{~mL}, \% 20$ 'lik TCA çözeltisi hazırlandı. $80 \mathrm{ml}$ çiğ süt örneğine, hazırlanan bu TCA'dan $70 \mathrm{ml}$ eklenerek oda sıcaklığında $10 \mathrm{dk}$ bekletildi. Bu karışımın $80 \mathrm{ml}$ 'lik kısmı $+4^{\circ} \mathrm{C}$ 'de $3000 \mathrm{rpm}$ de soğutmalı santrifüjde santrifüj edildi. Santrifüj sonrası oluşan serumlardan 40'ar ml'lik örnekler beherlere alınarak üzerlerine 4'er ml derişik nitrik asit (der. $\mathrm{HNO}_{3}$ ) eklendi. Hacimleri yarıya ininceye kadar serumlar $200^{\circ} \mathrm{C}^{\prime}$ de 1 sitıldi. Yaklaşı 20 ml olan serumlar ısıtıcı tabladan indirilerek oda sıcaklığına kadar bekletilerek soğutulduktan sonra tekrar 1sıtıcı tabla üzerinde üzerlerine 2'şer $\mathrm{ml}$ der. $\mathrm{HNO}_{3}$ eklenerek aynı sıcaklıkta $15 \mathrm{dk}$ buharlaştırıldı. Tekrar oda sıcaklığına gelinceye kadar soğutuldu. Serumların üzerine $4 \mathrm{ml} \% 30$ 'luk Hidrojen Peroksit $\left(\mathrm{H}_{2} \mathrm{O}_{2}\right)$ ve $2 \mathrm{ml}$ derişik sülfirik asit (der. $\left.\mathrm{H}_{2} \mathrm{SO}_{4}\right)$ eklendi. Çözeltinin rengi kahverengine dönüşünceye kadar $200^{\circ} \mathrm{C}^{\prime}$ de 1 sitılarak $15 \mathrm{dk}$ buharlaşması beklendi. Serumlar tekrar oda sıcaklığına kadar soğutuldu ve ardından üzerlerine 2'şer ml derişik perklorik asit (der. $\left.\mathrm{HClO}_{4}\right)$ eklendi. Hacim 10 ml'ye ininceye kadar 1sıtıldıktan sonra oda sıcaklığına kadar soğutuldu. Üzerlerine distile su eklenerek $20 \mathrm{ml}$ 'ye seyreltildi. Derişik asitlerden dolayı ortamda oluşan proteinleri çökertmek için örnekler $4000 \mathrm{rpm}$ de santrifüj edildi. Kör için cam behere $40 \mathrm{ml}$ saf su, $35 \mathrm{ml} \% 20$ 'lik TCA, $6 \mathrm{ml}$ der. $\mathrm{HNO}_{3}, 2 \mathrm{ml}$ der. $\mathrm{H}_{2} \mathrm{SO}_{4}$, $2 \mathrm{~mL}$ der. $\mathrm{HCIO}_{4}, 4 \mathrm{~mL} \mathrm{H} \mathrm{H}_{2} \mathrm{O}_{2}$ konuldu ve 1 sitıcida $200^{\circ} \mathrm{C}$ de yaklaşı $20 \mathrm{ml}$ hacme inene kadar buharlaştırıldı. Oluşan çözelti saf su ile (1:1) oranında seyreltildi. Bu işlemin ardından hazırlanan numuneler köre karşı atomik absorbsiyon spektrofotometresinde (AAS) (Pelkin elmer A Analyst 400) analiz edildi (Şimşek ve ark., 2000; Laçın, 2005). Çalışmaya konu olan Kurşun (Pb), Kobalt (Co), Kadminyum (Cd), Krom (Cr) ve Bakır (Cu) analizlerinin çalışma koşulları ve kalibrasyon eğrileri Şekil 1 'de verilmiştir. Yapılan bu çalışmada, elde edilen sonuçlara göre bulgular ppm düzeyinde verilmiştir $(1 \mathrm{mg} / \mathrm{L})$. 


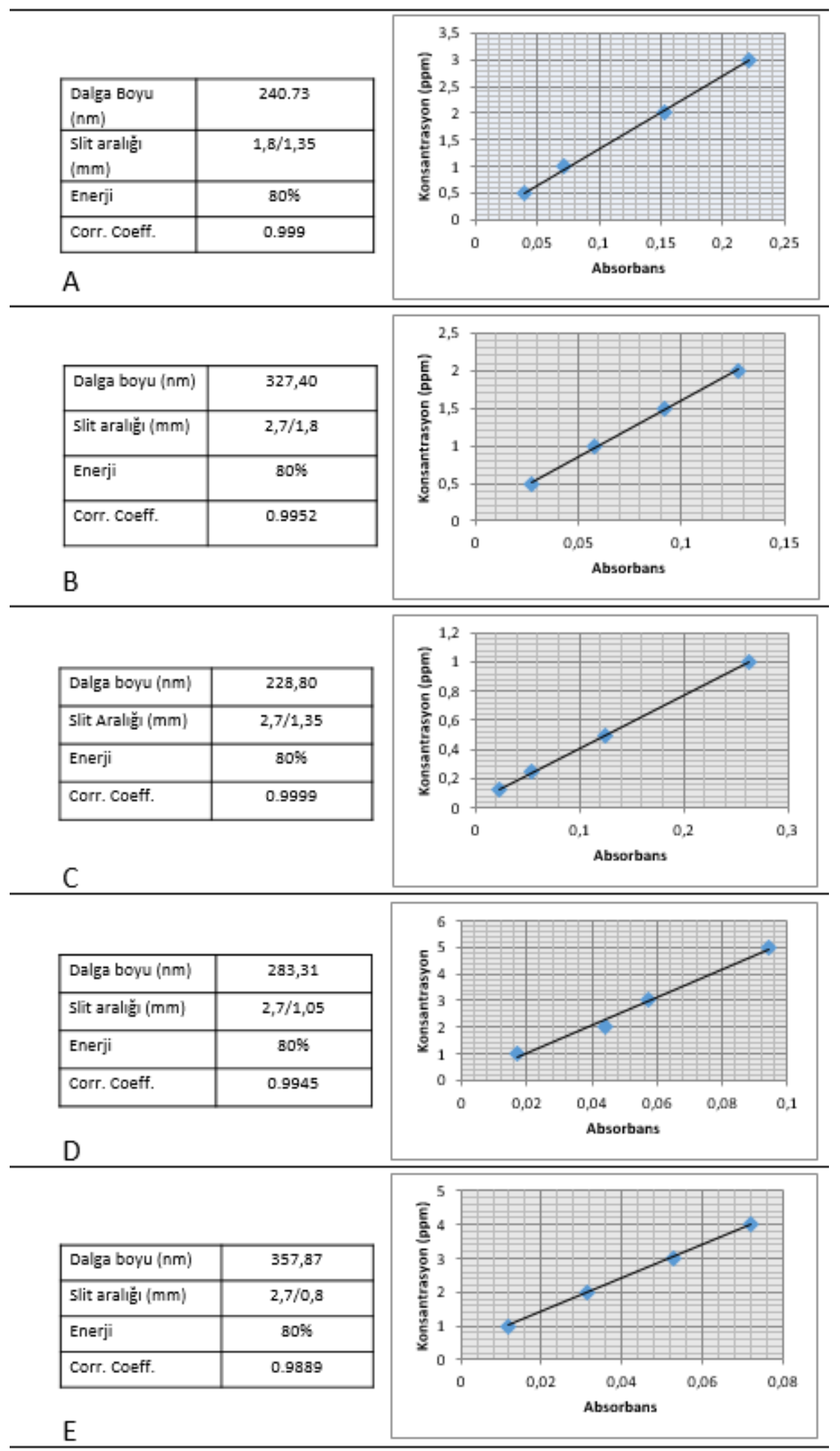

Şekil 1. Çalışmaya konu olan metal ve ağır metallerin AAS cihazındaki çalışma koşulları ve kalibrasyon ĕgrileri. (A) Co Analizi için Çalışma Koşulları ve Kalibrasyon Eğrisi, (B) Cu Analizi için Çallşma Koşullart ve Kalibrasyon Eğrisi, (C) Cd Analizi için çalışma koşulları ve Kalibrasyon Ĕ̆risi, (D) Pb Analizi için Çalışma Koşulları ve Kalibrasyon Ĕgrisi, (E) Cr Analizi için çalışma koşullarl ve Kalibrasyon Eğrisi 


\section{Sonuçlar ve Tartışma}

Süt toplama merkezlerinden alınan çiğ süt örneklerinde AAS yöntemiyle yapılan ağır metal ve metal konsantrasyonları belirleme analizlerine bakıldığında; $\mathrm{Cr}$ konsantrasyonunun; $0.245 \mathrm{ppm}$ ile en yüksek oranda Yumrutaş 1. Bölge'den alınan çiğ süt örneklerinde fazla olduğu görülürken; ikinci olarak 0.225 ppm ile Kargın, son olarak da 0.197 ppm ile Yumrutaş 2. Bölge'de olduğu görüldü. Bademli Beldesi süt toplama merkezinden alınan çiğ süt örneklerinde Cr'a rastlanmamıştır (Şekil 2).

Toplanan çiğ süt örneklerinde Cu konsantrasyonlarına bakıldığında, bu metalin, 0.067 ppm ile en yüksek oranda Kargın Beldesi'nde, ikinci olarak 0.032 ppm ile Bademli Beldesi'nde toplanan çiğ süt örneklerinde bulunduğu gözlemlenmiştir. Yumrutaş Beldesi'nde toplanan çiğ süt örneklerinde Cu'ya rastlanmamıştır (Şekil 2).

Cd, 0,567 ppm ile en yüksek oranda Yumrutaş 2. Bölge'de toplanan çiğ süt örneklerinde bulunurken, sırasıyla Kargın Beldesi'nde $0.542 \mathrm{ppm}$; Yumrutaş 1. Bölge'de 0,5 ppm ve son olarak Bademli Beldesi'nde 0,486 ppm oranlarında Cd miktarı hesaplanmıştır (Şekil 2).

Kargın Beldesi’nden alınan çiğ süt örneklerinde $\mathrm{Pb}, 0,574$ ppm ile en yüksek oranda gözlenirken; Bademli Beldesi, Yumrutaş 2. bölge ve Yumrutaş 1. bölgelerde toplanan çiğ süt örneklerinde sırasıyla 0,388 ppm; 0,154 ppm ve 0,145 ppm oranlarında Pb'ye rastlanılmıştır (Şekil 2).

Son olarak, Kargın Beldesi'nde 0,45 ppm; Yumrutaş 1. Bölge'de 0,448 ppm; Bademli Beldesi'nde 0,336 ppm ve Yumrutaş 2. Bölge'de 0,208 ppm oranlarında Co bulunmuştur (Şekil 2).

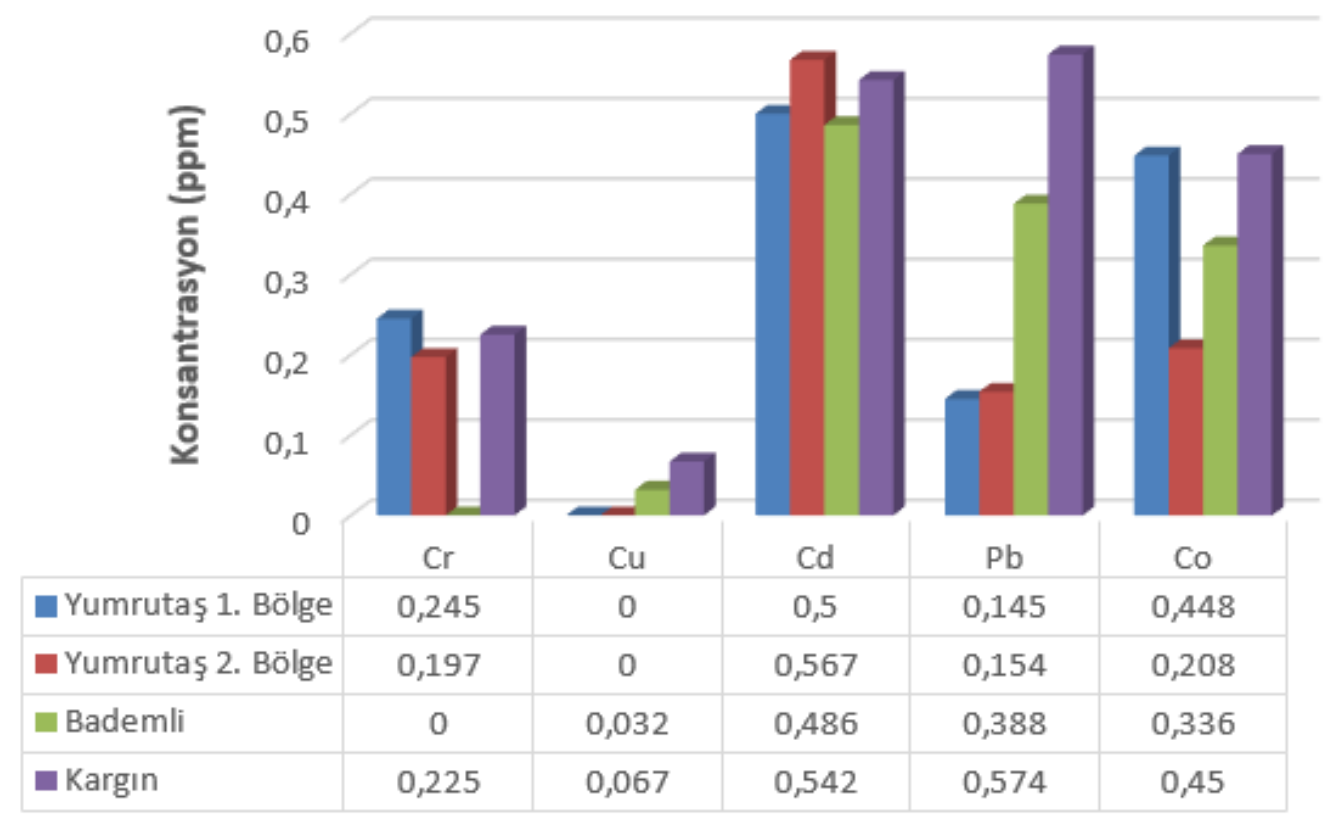

Şekil 2. Toplanan çĭ̆ süt örneklerindeki ağır metal ve metal konsantrasyonlart 
Akut ve/veya kronik sağlık sorunlarına neden olmaları nedeniyle ulusal ve uluslararası gıda örgütleri ağır metal kontaminasyonunun önlenmesi amacıyla düzenlemeler getirmiştir. Dünya Gıda ve Tarım Örgütü (FAO) ve Dünya Sağlık Örgütü (WHO)'nün Ortak Uzmanlar Komitesi (JECFA) tarafindan belirlenen mevzuata göre, çalışmaya konu olan metallerden $\mathrm{Pb}$, yetişkinlerde haftada $0,025 \mathrm{mg} / \mathrm{kg}$; $\mathrm{Cd}$, yetişkinlerde $0,007 \mathrm{mg} / \mathrm{kg}$ ve $\mathrm{Cu}$ ise yetişkinlerde günde $0,5 \mathrm{mg} / \mathrm{kg}$ sınırı geçemeyeceği ve tolere edilebilir maksimum düzeylerin bu miktarlar olduğu bildirilmiştir. Avrupa Komisyonu (EC) ve Türk Gıda Kodeksi (TGK)'ne göre çiğ süt ve bebek formüllerinde $\mathrm{Pb}, 0,02 \mathrm{mg} / \mathrm{kg}$ yaş ağrılık oranını geçemeyeceği rapor edilmiştir (Türközü, 2014).

Literatürde yapılan çalışmalara bakıldığında, Laçin'in (2005) üç ayrı ticari sütte AAS ile yaptıkları çalışmada tespit edilebilir düzeyde Pb bulunmadığını, Aktan ve ark. (1991), yaptıkları çalışmada $8,52 \pm 1,64 \mu \mathrm{g} / \mathrm{L}$ oranlarında $\mathrm{Pb}$ bulduğu bildirilmiştir. Rodriguez ve ark., (1999) çiğ sütte $14,82 \mu \mathrm{g} / \mathrm{L}$, pastörize sütte $10,25 \mu \mathrm{g} / \mathrm{L}$ ve keçi sütünde $11,86 \mu \mathrm{g} / \mathrm{L}$; süt ve ürünleri ile yaptıkları çalışmalarda, Licata ve ark., (2004) 1,32 $\mu \mathrm{g} / \mathrm{kg}$, Ataro ve ark., (2008) 0,136 ile 19,7 $\mu \mathrm{g} / \mathrm{L}$ arasinda, Sola-Larranaga ve Navarro-Blasco (2009) 5,23 $\mu \mathrm{g} / \mathrm{L} \mathrm{Pb}$ değerleri tespit ettiklerini bildirmişlerdir. Şimşek ve ark. (2000), Bursa ve çevresinde trafik bölgesi, endüstri bölgesi ve kırsal kesimden alınan süt numunelerinde sırasıyla $0,032 \mathrm{mg} / \mathrm{kg} ; 0,049 \mathrm{mg} / \mathrm{kg} ; 0,018 \mathrm{mg} / \mathrm{kg}$ oranlarında $\mathrm{Pb}$ varlı̆̆ını bildirmişler ve böylece endüstrileşmenin ağır metal kontaminasyonu bakımından süt ve ürünlerine olan katkısını rapor

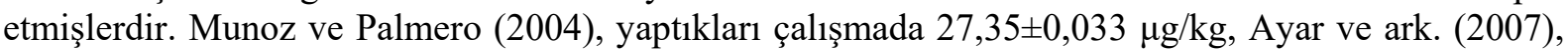
yaptıkları çalışmada $0,103 \pm 0,14 \mathrm{mg} / \mathrm{kg}$, Qin ve ark. (2009), 4 ayrı ticari sütte sırasıyla, $35,01 \pm 8,63$ $\mu \mathrm{g} / \mathrm{kg} ; 32,97 \pm 11,24 \mu \mathrm{g} / \mathrm{kg} ; 11,98 \pm 3,27 \mu \mathrm{g} / \mathrm{kg} ; 12,95 \pm 2,94 \mu \mathrm{g} / \mathrm{kg}$ ve çiğ sütte $28,15 \pm 11,23 \mu \mathrm{g} / \mathrm{kg} \mathrm{Pb}$ tespit etmişlerdir. Yapılan bu çalışmada elde edilen sonuçlara göre bulgular ppm düzeyinde verilmiştir. Topladığımız çiğ süt örneklerinde Pb miktarı, gerek Dünya Gıda ve Tarım Örgütü (FAO) ve Dünya Sağlık Örgütü (WHO)'nün Ortak Uzmanlar Komitesi (JECFA) tarafindan belirlenen mevzuata göre süt ve ürünleri ile gıdalarda tolere edilebilir miktarın ve gerekse literatürde yapılan çalışmalarda elde edilen sonuçların üzerinde bulunmuştur.

Lante ve ark.. (2006), yaptıkları çalışmalarda sütlerde Cd saptayamadıklarını, Ataro ve ark. (2008),

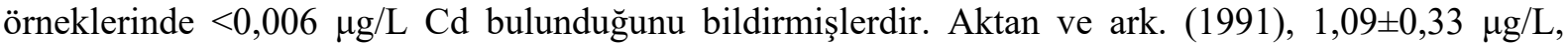
Rodriguez ve ark., (1999), çiğ sütte 4,88 $\mu \mathrm{g} / \mathrm{L}$, pastörize sütte $4,30 \mu \mathrm{g} / \mathrm{L}$, keçi sütünde 7,81 $\mu \mathrm{g} / \mathrm{L}$; Licata

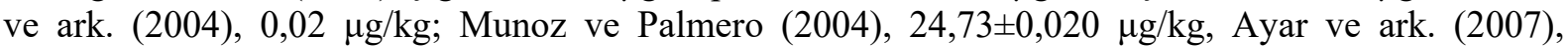
$0,017 \pm 0,010 \mathrm{mg} / \mathrm{kg}$; Sola-Larranaga ve Navarro-Blasco (2009), 0,40 $\mu \mathrm{g} / \mathrm{L}$, Qin ve ark. (2009), 4 ayr1 ticari sütte sirasıyla $4,53 \pm 3,01 \mu \mathrm{g} / \mathrm{kg} ; 4,25 \pm 3,03 \mu \mathrm{g} / \mathrm{kg} ; 1,13 \pm 0,64 \mu \mathrm{g} / \mathrm{kg} ; 2,01 \pm 1,06 \mu \mathrm{g} / \mathrm{kg}$ ve çiğ sütte $4,19 \pm 3,80 \mu \mathrm{g} / \mathrm{kg}$ Cd tespit ettiklerini bildirmişleridir. Yapılan bu çalışmada elde edilen Cd miktarı ppm düzeyinde yaklaşık olarak 0,5 ppm olarak bulunmuştur. Bu sonuç yetişkinler için gıdalarla alınan tolere edilebilir haftalık mitarla eşit gibi görünse de, başta TGK ve EC örgütleri olmak üzere ve JECFA tarafından ayrıca süt ve ürünlerinde bu ağır metal ile ilgili bulunması gereken maksimum oran belirtilmediği için sütte bu miktarın toksik etki yaratacağını düşünmekteyiz.

Şimşek ve ark. (2000), endüstriyel gelişimlerine göre sınıflandırdığı bölgelerde yaptığ çalışmaya göre; trafik bölgesi, endüstri bölgesi ve kırsal kesimden alınan süt numunelerinde sırasıyla $0,58 \mathrm{mg} / \mathrm{kg}, 0,96$ $\mathrm{mg} / \mathrm{kg}$ ve 0,39 mg/kg; Licata ve ark. (2004), $1,98 \mu \mathrm{g} / \mathrm{kg}$; Munoz ve Palmero (2004), 20,14 $\pm 0,020 \mu \mathrm{g} / \mathrm{kg}$; Sola-Larranaga ve Navarro-Blasco (2009), 51,8 $\mu \mathrm{g} / \mathrm{L}$; Qin ve ark. (2009), 4 ayrı ticari sütte ve çiğ sütte $0,17 \pm 0,06 \mathrm{mg} / \mathrm{kg}, 0,28 \pm 0,06 \mathrm{mg} / \mathrm{kg}, 0,23 \pm 0,02 \mathrm{mg} / \mathrm{kg}, 0,33 \pm 0,05 \mathrm{mg} / \mathrm{kg}$ ve $0,17 \pm 0,08 \mathrm{mg} / \mathrm{kg} \mathrm{Cu}$ tespit etmişlerdir. Çalışmamızda sütte bulunan $\mathrm{Cu}$ miktarı 0,01 ppm'in altında olup ayrıca iki bölgemizde de bu elemente rastlanmamıştır. Bu açıdan literatür verilerine göre topladığımız süt örneklerinde $\mathrm{Cu}$ miktarı Sola-Larranaga ve Navarro-Blasco'nun yaptığı çalışmaların elde ettiği sonuçların altında kalmıştır. Ülkemizin çeşitli bölgelerinde yapılan süt ve ürünlerinde ağır metal ve metal kontaminasyon çalışmalarında, kontaminasyon faktörlerini belirtmek için genellikle $\mathrm{As}, \mathrm{Pb}, \mathrm{Cd}$ gibi ağır metallerin kullanıldığı görülmektedir. Bunun sebebi As, $\mathrm{Pb}$, Cd'un ağır metaller grubunda değerlendirilmesi, diğerlerinin ise esansiyel metaller ya da elementler olarak değerlendirilmesi olabilir. Bu elementlerin de vücutta birikiminin toksik etki yaratacağı düşünüldüğünde çalışmamızda toplanan süt örneklerinde 
ayrıca literatürden farklı olarak $\mathrm{Cr}$ ve Co metalleri çalışılmış ve sırasıyla yaklaşık olarak örneklerde 0,2 ve 0,4 ppm oranında bu metaller tespit edilmiştir.

Gerek esansiyel metal olarak gerekse ağır metal formu olarak, tüketilen gıdalardan aşırı miktarlarda bu elementlerin vücuda alınması ve vücutta birikmesi insan sağlığını önce toksikolojik açıdan sonrada gelişebilecek kronik hastalıklar açısından sıkıntıya sokmaktadır. Yapılan çalışmalar yüksek doz metal ve ağır metal maruziyetinin insanlarda, akut olarak proksimal renal tübüler hasara, kronik olarak sinir sistemi bozuklukları, anemi, kronik böbrek yetmezliği, körlük, kolik, D vitamini metabolizmasında bozukluklara, gastrointestinal sistem hasarlarına, demir metabolizmasında bozukluklara, kardiyovasküler sistem bozukluklarına, osteoporoz ve osteomalasiaya gibi iskelet sistemi bozukluklarına, nörodejeneratif hastalıklara, büyüme gelişme bozukluklarına ve başta akciğer, böbrek, mesane, prostat kanserleri olmak üzere çeşitli kanser türlerine neden olduğu bildirmiştir (Türközü 2014).

$\mathrm{Bu}$ çalışmada metodolojik olarak AAS yöntemi kullanılmıştır. Literatürde bu tip çalışmalara bakıldığında İndüktif olarak Birleştirilmiş Plazma - Kütle Spektrometresi (ICP-MS) ve İndüktif olarak Birleştirilmiş Plazma - Atomik Emisyon Spektrometresi (ICP-AES) yöntemlerinin de kullanıldığı görülmektedir. Bu yöntemler kantitasyon bakımından AAS yöntemine oranla daha spesifik sonuçlar verecektir. Bu ve buna benzer çalışmalarda sonuçların spesifik ve daha güvenilir olması için alınacak yeni numunelerde ICP-AES ve ICP-MS gibi yöntemlerle çalışılması gerektiğini ve AAS yöntemleriyle elde edilen sonuçlarla da karşılaştırılması gerektiğini düşünüyoruz.

Sonuç olarak, özetle; yapılan bu çalışmada Acıpayam İlçesi süt toplama merkezlerindeki sütlerin ağır metal ve metal kontaminasyonları belirlenmiştir. Buna göre eldeki literatür verilerine göre ayrıca Türk Gıda Kodeksi, Dünya sağlı Örgütü'nün bildirgelerine göre yüksek oranda ağır metal kontaminasyonuyla karşıllaşılmıştır. Öncelikli yapılması gerekenlerin;

- Bu kontaminantların günlük, haftalık ve aylık tolere edilebilir miktarlarının belirlenmesi gerektiğini, buna göre tolere edilebilir miktarın üzerinde kontamine süt içimi ve süt ürünleriyle beslenme, çocukluk çağı başta olmak üzere çeşitli önlenemez hastalıkların oluşmasına yol açacağının unutulmaması gerektiğini

- Bu bölgelerimizde ağır metallerin süte bulaşma kaynakları önceden belirlenmesi gerektiğini, kirletici unsurlar toprak ve yem kökenli ise öncelikle bu alanlarda biyoremidasyon gibi çeşitli yöntemlerle ıslah çalışmalarının yapılması gerektiğini,

- Süt toplama merkezlerinin çalışma saatleri sırasında hijyen kurallarına uyulup uyulmadığının kontrol edilmesi gerektiğini ve bu konuda görevli kişilere eğitici programların verilerek sütlerin daha efektif toplanmasının sağlanmasını

- Özellikle süt toplama merkezlerinde gelişi güzel bulunan ağzı açık süt toplama tanklarının havada aerosol etkisi yapan bu ağır metallerin, toz, taşıt egzoz dumanı, baca dumanı gibi etkenlere maruz kalması toplanan sütlerin kontaminasyonunu hızlandıracağının unutulmaması gerektiğini ve bu nedenle süt toplama merkezlerinin toz, duman, egzoz gazından uzak olacak şekilde kurulması ve korunaklı olması gerektiğini savunuyor ve düşünüyoruz.

\section{Teşekkür}

Bu çalışma 2012 y1lında, eski adı Kırıkkale Üniversitesi Bilimsel ve Teknolojik Araştırma Laboratuvarları (KÜBTAL), yeni adı Kırıkkale Üniversitesi Bilimsel ve Teknolojik Araştırmalar Uygulama ve Araştırma Merkezi (KÜBTUAM)'nin Kimyasal Analiz Laboratuvarları kullanılarak yapılmıştır. Desteklerinden dolayı KÜBTUAM Müdürlüğü'ne teşekkür ederiz. Ayrıca bu çalışma 1516 Kasım 2012 tarihleri arasında Denizli'de düzenlenen "Süt Endüstrisinde Yenilikçi Yaklaşımlar Sempozyumu'nda poster bildiri olarak sunulmuştur. 


\section{Kaynaklar}

Aktan, H.T., Sayal A., Aydın, A., Mutluer, B., Işımer A. 1991. İnek sütlerindeki kurşun ve kadmiyum miktarları üzerinde araştırma, A.Ü. Veteriner Fakültesi. Dergisi, 38(1-2), 100-107.

Ataro, A., Mccrindle, R.I., Botha, B.M., Mccrindle, C.M.E., Ndibewu, P.P. 2008. Quantification of trace elements in raw cow's milk by inductively coupled plasma mass spectrometry (ICP-MS), Food Chemistry. 111, 243-248.

Ayar, A., Sert, D., Akın, N. 2007. Konya'da tüketime sunulan süt ve ürünlerinin ağır metal içeriklerinin belirlenmesi. Selçuk Üniversitesi Ziraat Fakültesi Dergisi 21(41), 58-64.

Baldın1, M., Con1, E., Stacchın1, A., Stacchın1, P. 1990. Presence and assessment of xenobiotic substances in milk and dairy products. Ann Ist Super Sanita. 26(2), 167-176.

Bigucu, E., Kaptan, B., Palabiyık, İ., Oksuz, O. 2016. The Effect of Environmental Factors on Heavy Metal and Mineral Compositions of Raw Milk and Water Samples. Journal of Tekirdag Agricultural Faculty. 13(04), 61-70.

Bratakos, Ms., Lazos, E.S., Bratakos, S.M. 2001. Chromium content of selected Greek foods. Sci Total Environ. 290, 47-58.

Campıllo, N., Vınas, P., Lopez-Garcia, I., Hernandez-Cordoba, M. 1998. Direct determination of copper and zinc in cow milk, human milk and infant formula samples using electrothermal atomization atomic absorption spectrometry. Talanta. 46, 615-622.

Con1, E., Carol1, S., Iann1, D., Bocca, A. 1994. A methodological approach to the assessment of trace elements in milk and dairy products. Food Chem 50, 203-210.

Con1, E., Bocca, A., Iann1, D., Carol1, S. 1995. Preliminary evaluation of the factors influencing the trace element content of milk and dairy products. Food Chem. 52, 123-130.

Conı, E., Bocca, A., Coppolell1, P., Carol1, S., Cavallucc1, C., Trabalza Marınucc1, M. 1996. Minor and trace element content in sheep and goat milk and dairy products. Food Chem. 57,253-260.

Conor, R. 2006, Pollutants in Food? Metals and Metalloids-Mineral Components in Foods, In Chemical \& Functional Properties of Food Components, pp. 363-88, CRC Press.

Duffus, J.H. 2002. Heavy metals a meaningless term? IUPAC Technical Report. Pure and Applied Chemistry. 74, 793-807.

http://www.tarim.gov.tr/SGB/TARYAT/Belgeler/il_yatirim_rehberleri/denizli.pdf Erişim tarihi: 06.03.2017.

Imparato, E., Esposito, M., De Grado, G., Grasso, L., Oliviero, G., Maddaluno, F. 1999. Livelli di piombo e cadmio, quali indicatori ambientali, nel latte in aziende zootecniche dell'Irpinia. Latte. 24(5), $106-109$.

İnci, A., Aypak, S. Ü., Güven, G., 2017. Aydın ilinde üretilen inek sütlerinde bazı ağır metal düzeylerinin araştırılması. Gıda. 42(3), 229-234.

Jarup, L. 2003. Hazards of heavy metal contamination. British medical bulletin. 68(1), 167-82. 
Jorhem, L., Slorach, S., Sundstrom, B., Ohlın, B. 1991. Lead, cadmium, arsenic and mercury in meat, liver and kidney of Swedish pigs and cattle in 1984- 88. Food Addit Contam. 2,201-212.

Kinca1d, Rl., Cronrath, Jd. 1992. Zinc concentration and distribution in mammary secretions of peripartum cows. J Dairy Sci. 75,481-490.

Krachler, M., Rossipal, E., Irgolic, Kj. 1998. Trace elements in formulas based on cow and soy milk and in Austrian cow milk determined by inductively coupled plasma mass spectrometry. Biol Trace Elem Res. 65, 53-57.

Laçın, A. 2005. Kahramanmaraş bölgesindeki Keçi Sütünde Eser Element Analizi, Kahramanmaraş Sütçü İmam Üniversitesi, Y. Lisans Tezi.

Lante, A., Lomolıno, G., Cagnın, M., Spettoli, P. 2006. Content and characterisation of minerals in milk and in crescenza and squacquerone Italian fresh cheeses by ICP-OES. Food Control. 17, 229-233.

Licata, P., Trombetta, D., Cristanı, M., Giofre, F., Martıno, D., Calo, M. And Naccar1, F. 2004. Levels of "toxic" and "essential" metals in samples of bovine milk from various dairy farms in Calabria, Italy. Environ Int. 30(1), 1-6.

Munoz, E., Palmero, S. 2004. Determination of heavy metals in milk by potentiometric stripping analysis using a home-made flow cell. Food Control. 15, 635-641.

Q1n, L. Q., Wang, X. P., L1, W., Tong, X., Tong, W. J. 2009. The minerals and heavy metals in cow's milk from China and Japan. Journal Health Science. 55(2), 300-305.

Pittıa, P., Mazzılıs, D., Dalla Rosa, M., Corradını, C. 1992. Indagine sul contenuto in piombo in latte della provincia di Udine. Sci Tec Latt-Casearia. 43(3), 201-218.

Re1lly, C. 1985. The dietary significance of adventitious iron, zinc, copper and lead in domestically prepared food. Food Additives \& Contaminants. 2(3), 209-215.

Rodriguez-Rodriguez, E.M., Delgado-Uretra, E., Diaz-Romero, C. 1999 Concentrations of cadmium and lead in different types of milk, Z Lebensm Unters Forsch A, 208, 162-168.

Salvato, N., Banf1, G., Taccan1, F., Rottol1, A., Banderar, G. 1992. Direct analysis of essential elements (chromium, copper, iron, manganese, selenium) in human milk by Zeeman GFAAS. Appl Zeeman Graphite Furn At Absorpt Spectrom Chem Lab Toxicol. 305-323.

Simsek, O., Gultekın, R., Oksuz, O., Kurultay, S. 2000. The effect of environmental pollution on the heavy metal content of raw milk. Nahrung-Food. 44, 360-371.

Sola-Larranaga, C., Navarro-Blasco, I. 2009. Chemometric analysis of minerals and trace elements in raw cow milk from the community of Navarra, Spain. Food Chemistry. 112, 189-196.

Temurci (Usta), H., Güner, A. 2006. Ankara'da Tüketime Sunulan Süt ve Beyaz Peynirlerde Ağır Metal Kontaminasyonu. Atatürk Üniversitesi Vet. Bil. Derg. 1(1-2), 20-28.

Türközü, D. Ve Şanlıer, N. 2014. Gıdalardaki Ağır Metal Kontaminasyonları: Bulaşma Kaynakları, Sağlık Riskleri ve Ulusal/Uluslararası Standartlar. Gıda Teknolojileri Elektronik Dergisi 9(3), 29-46. 
